\title{
EFEKTIVITAS ISOLAT Trichoderma spp. DALAM PENGENDALIAN PENYAKIT AKAR GADA (Plasmodiaphora brassicae Wor.) PADA SAWI HIJAU (Brassica rapa)
}

\author{
Ni Putu Pandawani, I Ketut Widnyana dan I Ketut Sumantra \\ Fakultas Pertanian dan Bisnis Universitas Mahasaraswati Denpasar \\ e-mail korespondensi: pandawaniputu@unmas.ac.id
}

\begin{abstract}
The study aims to determine the effectiveness of the dose and age of culture of Trichoderma spp. in controlling clubroot disease in mustard plants. Factorial RAK is used in research with 2 factors and 3 replications. The first factor was the dose of Trichoderma spp. which consists of 3 dosage levels, namely $500 \mathrm{ml} ; 250 \mathrm{ml}$ and $0 \mathrm{ml}$. The second factor is the age of culture of Trichoderma spp. consisting of 3 liver ages of Trichoderma spp isolates, namely 1 week age of culture; 2 weeks of age and 3 weeks of culture. On mustard plants infected with clubroot, treatment of several doses of Trichoderma spp. and treatment of several age cultures from Trichoderma spp. give significantly different effect on the height of mustard plants, mustard leaves and percentage of disease. Treatment of Trichoderma spp. $500 \mathrm{ml}$ dose produced plant height of $21.68 \%$ and plant leaves $26.63 \%$ significantly higher than plant height and leaves in the treatment without Trichoderma spp isolates. Treatment of Trichoderma spp. with 2 weeks of age, the plant height was $12.80 \%$ and the leaves were $16.04 \%$ significantly higher, compared to the height and leaves of the plants in the treatment of Trichoderma spp. 1 week culture. Percentage of clubroot disease in mustard plants in the combination of Trichoderma spp. the $500 \mathrm{ml}$ culture dose and the culture age of Trichoderma spp isolate 2 weeks, reached $0 \%$, which means that without the attack of clubroot.
\end{abstract}

Keywords: effectiveness, Trichoderma spp., clubroot, age of culture, mustard greens

\begin{abstract}
Abstrak. Penelitian bertujuan untuk mengetahui efektifitas dosis dan usia biakan dari isolat Trichoderma spp. dalam pengendalain penyakit akar gada pada tanaman sawi. RAK Faktorial digunakan pada penelitian dengan 2 faktor dan 3 ulangan. Faktor pertama adalah dosisdari isolat Trichoderma spp. yang terdiri dari 3 level dosis, yaitu $500 \mathrm{ml} ; 250 \mathrm{ml}$ dan $0 \mathrm{ml}$. Faktor kedua adalah usia biakan dari isolate Trichoderma spp. yang terdiri dari 3 lever usia biakan isolate Trichoderma spp yaitu usia biakan 1 minggu; usia biakan 2 minggu dan usia biakan 3 minggu. Pada tanaman sawi yang terinfeksi penyakit akar gada, perlakuan beberapa dosis isolat Trichoderma spp. dan perlakuan beberapa usia biakan dari Trichoderma spp. memberikan pengaruh yang berbeda nyata terhadap variabel tinggi tanaman sawi, daun tanaman sawi dan persentase penyakit. Perlakuan dari isolat Trichoderma spp. dosis $500 \mathrm{ml}$ menghasilkan tinggi tanaman 21,68\% dan daun tanaman $26,63 \%$ lebih tinggi secara nyata dibandingkan dengan tinggi tanaman dan daun pada perlakuan tanpa pemberian isolat Trichoderma spp. Perlakuan dari isolat Trichoderma spp. dengan usia biakan 2 minggu, menghasilkan tinggi tanaman 12,80\% dan daun 16,04\% nyata lebih tinggi, dibandingkan dengan tinggi dan daun tanaman pada perlakuan isolat Trichoderma spp. usia biakan 1 minggu . Persentase penyakit akar gada pada tanaman sawi pada perlakuan kombinasai isolat Trichoderma spp. dosis biakan $500 \mathrm{ml}$ dan usia biakan isolat Trichoderma spp 2 minggu, mencapai $0 \%$, yang berarti tanpa adanya serangan penyakit akar gada.
\end{abstract}

Kata kunci: efektifitas, Trichoderma spp., penyakit akar gada, usia biakan, sawi hijau

\section{PENDAHULUAN}

Sawi hijau ( Brassica rapa ) merupakan jenis sayuran yang cukup populer. Tanaman sawi dapat tumbuh baik di tempat yang berhawa panas maupun berhawa dingin, sehingga dapat diusahakan dari dataran rendah maupun dataran tinggi. Usaha budidaya sawi hijau dilapang, tidak terlepas dari gangguan penyakit yang dapat mengakibatkan penurunan kuantitas dan kualitas produksi dan bahkan dapat mengakibatkan kegagalan panen.

Salah satu penyakit yang sering ditemui pada tanaman sawi hijau adalah penyakit akar gada. Penyakit akar gada disebabkan oleh patogen tular tanah (Plasmodiophora 
brassicae Wor.) merupakan penyakit penting pada tanaman kubis dan tanaman cruciferae lainnya. Patogen tular tanah (Plasmodiophora brassicae Wor.) ini menyebabkan pembengkakan pada akar dan juga pada pangkal batang. Pembengkakan akar merupakan ciri khas penyakit akar gada. Bentuk dan letaknya bergantung pada spesies inang dan tingkat infeksi. Akar yang membengkak akan makin besar dan biasanya hancur sebelum akhir musim tanam karena serangan bakteri dan isolat lain (Arismansyah, 2010).

Penyakit akar gada sulit dikendalikan karena patogen dapat bertahan lama dalam tanah meskipun tanpa tanaman inang sehingga perlu adanya upaya pengembangan pengendalian penyakit yang bersifat berkelanjutan. Pengendalian secara kimiawi pada umumnya masih mengandalkan penggunaan fungisida sintetik, namun penggunaan secara berkepanjangan dapat berdampak negatif bagi ekosistem (Alfizar et al., 2013; Mahartha et al., 2013). Salah satu alternatif untuk mengantisipasi dampak tersebut adalah melalui pengendalian biologi dengan memanfaatkan Agen Pengendali Hayati. APH dapat dimanfaatkan karena mampu membatasi pertumbuhan patogen untuk waktu yang lebih lama, tidak meninggalkan residu dan menjaga keseimbangan ekosistem.

Pengendalian secara biologi atau pengendalian secara hayati dengan memanfaatkan mikroba antagonis merupakan suatu bagian komponen pengendalian yang penting untuk pengelolaan penyakit akar gada. Penanggulangan penyakit akar gada perlu dilakukan secara terintegrasi dan memanfaatkan mikroorganisme antagonis alami dalam tanah melalui aplikasi mikroba antagonis seperti Mortierella sp., Trichoderma spp. Gliocladium sp., Chaetomium sp., Pseudomonas spp. Phoma glomerata, dan $H$. chaetospira. (Pratiwi et al., 2015). Keberadaan jamur antagonis yang mudah ditemukan pada ekosistem pertanian dapat dimanfaatkan sebagai agen pengendali hayati. Jamur antagonis yang sangat umum ditemukan adalah Trichoderma spp. (Rao, 2010).

Jamur Trichoderma spp. merupakan salah satu jenis yang banyak dijumpai pada semua jenis tanah dan pada berbagai habitat yang merupakan salah satu jenis jamur yang dapat dimanfaatkan sebagai agensia hayati pengendali patogen tanah dan telah menjadi perhatian penting sejak beberapa dekade terakhir ini, karena kemampuannya sebagai pengendali biologis terhadap beberapa pathogen tanaman (Carreras-Villaseñor et al., 2012). Populasi Trichoderma spp., dalam tanah sangat berperan dalam kemampuan pengendalian penyakit. Pertumbuhan hifa Trichoderma spp. yang memanjang dan memasuki tubuh inang juga sangat menentukan kemampuan atau keberhasilan pengendalian inang suatu penyakit (Sudantha \& Abadi, 2011).

Trichoderma diketahui mempunyai sifat antagonistik terhadap jasad lain terutama terhadap patogen akar membuka kemungkinan untuk dikembangkan. Penelitian ini bertujuan untuk mengetahui efektifitas dari isolat Trichoderma spp pada beberpa dosis dan usia biakan isolat Trichoderma spp. dalam usaha pengendalain penyakit akar gada pada tanaman sawi hijau (Brassica rapa). 


\section{METODE}

Penelitian dilaksanakan bulan Januari sampai Mei 2019 di Desa Sumerta, Kecamatan Denpasar Timur, Kota Denpasar dan Laboratorium Hama dan Penyakit Tumbuhan Fakultas Pertanian dan Bisnis Universitas Mahasaraswati Denpasar. Bahan-bahan yang dipergunakan adalah isolat Trichoderma spp., beras, aquadest, bibit tanaman sawi, tanaman sawi sakit terinfeksi penyakit akar gada, polybag, pot plastik, tanah media tanam, pupuk kandang, Urea, $\mathrm{KCl}$ dan TSP. Alat yang digunakan adalah autoclave, laminar airflow, lampu bonsen, timbangan, blender, gelas ukur, pinset, kantong plastik dan kertas label.

Penelitian

dirancang

menggunakan Rancangan Acak Kelompok Faktorial dengan tiga

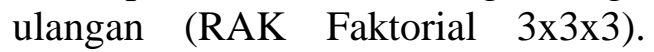
Perlakuan yang diteliti sebagai faktor pertama adalah dosis isolat Trichoderma spp. (D) dan faktor kedua usia biakan isolat Trichoderma spp. pada media beras (U). Faktor dosis isolat Trichoderma spp., terdiri dari 3 level yaitu: D0 (tanpa pemberian isolat Trichoderma spp.); $\mathrm{D} 1(250 \mathrm{ml}$ larutan biakan Trichoderma spp); D2 (500 ml larutan biakan isolat Trichoderma spp). Faktor usia biakan isolat Trichoderma spp. terdiri dari 3 level yaitu : U1(usia biakan 1 minggu); U2 (usia biakan 2 minggu); U3 (usia biakan 3 minggu). Dari faktor-faktor tersebut mendapatkan 9 perlakuan kombinasi. Setiap perlakuan kombinasi dalam setiap ulangan terdiri dari 5 pot, sehingga jumlah pot seluruhnya 135 pot.

Penelitian dilaksanakan dalam beberapa tahapan kegiatan yaitu:
1) Pembiakan isolat di laboratorium dari isolat murni pada PDA ke media beras.

Beras dicuci dan dimasak selama \pm 45 menit. Beras yang telah dimasak dituang di atas nampan, selanjutnya dibiarkan sampai dingin. Setelah dingin $100 \mathrm{~g}$ media beras tersebut dimasukkan ke kantong plastik. Media beras dalam kantong plastik disterilisasi dalam autoclave salama 45 menit. Setelah diautoclave media didinginkan dan selanjutnya media diinokulasikan isolat murni Trichoderma spp. yang tersedia dalam media PDA (isolat koleksi Laboratorium HPT, FP Unmas Denpasar ) dan dilakukan dalam Laminar air flow. Media biakan beras yang telah diinokulasi isolat Trichoderma Spp, disimpan pada kondisi ruangan dan tidak terkena cahaya matahari langsung. Miselium isolat Trichoderma Spp., akan tumbuh memenuhi media beras dalam waktu 7-10 hari dan selanjutnya siap untuk dipindahkan pada media sekam. Waktu pembiakan ini diatur dengan selang waktu 1 minggu, disesuaikan dengan perlakuan waktu aplikasi, yaitu dimulai dari perlakuan usia biakan 3 minggu (U3), 2 minggu (U2) berikutnya untuk perlakuan usia biakan 1 minggu (U1).

\section{2). Pembibitan.}

Benih sawi setelah direndam dalam air selama \pm 24 jam langsung ditanam pada polybag pembibitan kapasitas $200 \mathrm{~g}$ media tanam dengan satu bibit per polybag Setelah tumbuh umur 23 hari bibit siap dipindahkan ke pot penelitian (ukuran $5 \mathrm{~kg}$ ) dengan 2 tanaman/pot.

3). Persiapan pot dan aplikasi Trichoderma spp.

Satu minggu sebelum tanam, pot percobaan kapasitas $5 \mathrm{~kg}$, disiapkan 
dan diisi media campuran dari $10 \mathrm{~kg}$ tanah, $5 \mathrm{~kg}$ pupuk kandang dan $100 \mathrm{~g}$ pupuk Urea. Penempatan perlakuan pada setiap ulangan dilakukan secara acak dengan diberi kode perlakuan dan ulangan. Pemupukan berikutnya dilakukan 1 minggu setelah tanam dengan $50 \mathrm{~g}$ TSP/pot dan $50 \mathrm{~g}$ $\mathrm{KCl} /$ pot. Waktu aplikasi isolat Trichoderma spp. dilakukan saat tanaman umur 2 minggu setelah tanam (2 Mst) sesuai dengan perlakuan kombinasi dosis yaitu D0, D1 dan D2 dengan usia biakan yaitu U1, U2 dan U3. Starter isolat Trichoderma spp. pada media padat beras sebanyak $100 \mathrm{~g}$ yang telah tumbuh, dilarutkan dalam $1000 \mathrm{ml}$ aquadest dan dihaluskan hingga menyerupai larutan tepung. Dosis D1 setiap pot disiramkan $250 \mathrm{ml}$ larutan tepung biakan isolat Trichoderma spp. dan untuk dosis D2 setiap pot disiramkan $500 \mathrm{ml}$ larutan tepung biakan isolat Trichoderma spp.

\section{4).Inokulasi Penyakit pada Tanaman.}

Sumber inokulum penyakit akar gada diambil dari tanaman sakit di lapang. Sumber inokulum penyakit dipersiapkan dengan cara sebagai berikut : $200 \mathrm{~g}$ sampel akar tanaman sakit dimasukan dalam $1000 \mathrm{ml}$ aquades dan dihaluskan hingga larut. Larutan akar tanaman sumber inokulum tersebut selanjutnya diinokulasikan ke tanaman sebanyak $200 \mathrm{ml} /$ pot pada saat tanaman umur 3 Mst.

\section{5). Pengamatan dan Analisis Data.}

Parameter yang diamati adalah tinggi tanaman, jumlah daun pertanaman, persentase serangan penyakit. Pengamatan dilakukan setiap minggu pada seluruh pot percobaan. Nilai parameter setiap perlakuan diambil dari rerata nilai pengamatan pada 5 pot (5 tanaman setiap perlakuan kombinasi). Data hasil pengamatan disusun dalam bentuk tabel dan dianalisis sesuai dengan analisis RAK faktorial dan uji lanjutan BNT pada taraf uji 5\% (Hanafiah, 2002).

\section{HASIL DAN PEMBAHASAN}

Hasil Analisa statistika (Tabel 1) menunjukkan bahwa pengaruh dosis dan usia biakan Trichoderma spp. pada tanaman sawi menunjukan pengaruh tidak berbeda nyata sampai sangat berbeda nyata pada semua parameter yaitu tinggi tanaman, jumlah daun dan persentase serangan penyakit akar gada. Pada pengamatan umur 2 Mst; 3 Mst; 4 Mst dan 5 Mst, perlakuan dosis Trichoderma spp. memberikan pengaruh yang sangat berbeda nyata terhadap parameter tinggi tanaman. Perlakuan usia biakan memberikan pengaruh yang sangat berbeda nyata terhadap tinggi tanaman pada umur 4 dan 5 Mst, sedangkan pada umur 3 Mst berbeda nyata dan tidak berbeda nyata pada umur 2 Mst. Pada pengamatan umur $2 \mathrm{Mst} ; 3 \mathrm{Mst}$; 4 Mst dan 5 Mst, perlakuan dosis Trichoderma spp. memberikan pengaruh yang sangat berbeda nyata terhadap parameter tinggi tanaman. Perlakuan usia biakan memberikan pengaruh yang sangat berbeda nyata terhadap tinggi tanaman pada umur 4 dan 5 Mst, sedangkan pada umur 3 Mst berbeda nyata dan tidak berbeda nyata pada umur 2 Mst. Pada pengamatan umur 1 Msi; 2 Msi dan 3 Msi, perlakuan dosis dan usia biakan Trichoderma spp. memberikan pengaruh yang sangat berbeda nyata terhadap parameter persentase serangan penyakit. Kombinasi perlakuan dosis dan usia biakan memberikan pengaruh persentase serangan yang tidak berbeda nyata 
pada pengamatan $1 \mathrm{Msi}$, berbeda nyata pada pengamatan 2 Msi dan

sangat berbeda nyata pada pengamatan 3 Msi.

Tabel 1. Signifikansi pengaruh perlakuan dosis dan usia biakan isolate Trichoderma spp.terhadap parameter pengamatan

\begin{tabular}{cccccccccc}
\hline Waktu & \multicolumn{10}{c}{ Parameter Pengamatan } \\
\cline { 2 - 10 } Pengamatan & \multicolumn{1}{c}{ Tinggi Tanaman } & \multicolumn{1}{c}{ Jumlah Daun } & \multicolumn{4}{c}{ Persentase Penyakit } \\
\cline { 2 - 10 } & D & U & DU & D & U & DU & D & U & DU \\
\hline 2 Mst & $* *$ & $\mathrm{~ns}$ & $\mathrm{~ns}$ & $* *$ & $* *$ & $*$ & - & - & - \\
$3 \mathrm{Mst}$ & $* *$ & $*$ & $\mathrm{~ns}$ & $* *$ & $* *$ & $\mathrm{~ns}$ & - & - & - \\
$4 \mathrm{Mst}$ & $* *$ & $* *$ & $\mathrm{~ns}$ & $* *$ & $* *$ & $\mathrm{~ns}$ & - & - & - \\
$5 \mathrm{Mst}$ & $* *$ & $* *$ & $*$ & $* *$ & $* *$ & $*$ & - & - & - \\
\hline $1 \mathrm{Msi}$ & - & - & - & - & - & - & $* *$ & $* *$ & $\mathrm{~ns}$ \\
$2 \mathrm{Msi}$ & - & - & - & - & - & - & $* *$ & $* *$ & $*$ \\
$3 \mathrm{Msi}$ & - & - & - & - & - & - & $* *$ & $* *$ & $* *$ \\
\hline
\end{tabular}

Keterangan: $\mathrm{D}=$ Dosis biakan Trichoderma spp. $\mathrm{U}=$ Usia biakan Trichoderma spp. DU= kombinasi perlakuan; ns $=$ tidak berbeda nyata; $*$ = berbeda nyata; $* *=$ berbeda sangat nyata; Mst $=$ minggu setelah tanam; Msi = minggu setelah inokulasi

\section{Tinggi Tanaman}

Hasil Analisa statistika (Tabel 2) menunjukkan bahwa perlakuan Trichoderma spp. dosis $500 \mathrm{ml}$ (D2) pada pengamatan umur $2 \mathrm{Mst} ; 3 \mathrm{Mst}$; 4 Mst dan 5 Mst, memberikan tinggi tanaman nyata tertinggi dibandingkan dengan perlakuan dosis $250 \mathrm{ml}(\mathrm{D} 1)$ dan perlakuan tanpa pemberian Trichoderma spp. (D0). Tinggi tanaman pada perlakuan dosis D2, pada pengamatan umur $2 \mathrm{Mst} ; 3 \mathrm{Mst}$; 4 Mst dan 5 Mst, berturut-turut adalah $16,90 \mathrm{~cm} ; 24,00 \mathrm{c} ; 30,00 \mathrm{~cm}$ dan $34,40 \mathrm{~cm}$ dengan presentase tinggi tanaman lebih tinggi $13,72 \%$; $16,61 \% ; 13,29 \%$ dan $14,24 \%$ dari perlakuan D1, serta lebih tinggi $29,20 \% ; \quad 28,47 \% ; \quad 26,15 \%$ dan $21,85 \%$ dari perlakuan D0.

Tabel 2. Tinggi tanaman sawi pada beberapa dosis dan usia biakan Trichoderma spp

\begin{tabular}{|c|c|c|c|c|}
\hline \multirow{2}{*}{ Perlakuan } & \multicolumn{4}{|c|}{ Tinggi tanaman sawi $(\mathrm{cm})$} \\
\hline & $2 \mathrm{Mst}$ & $3 \mathrm{Mst}$ & $4 \mathrm{Mst}$ & $5 \mathrm{Mst}$ \\
\hline \multicolumn{5}{|l|}{ Dosis } \\
\hline D 0 & $14,18 \mathrm{a}$ & 19,78 a & $24,88 \mathrm{a}$ & $29,33 \mathrm{a}$ \\
\hline D 1 & $15,96 \mathrm{~b}$ & 20168 b & $27,58 \mathrm{~b}$ & $31,21 \mathrm{~b}$ \\
\hline $\mathrm{D} 2$ & $17,00 \mathrm{c}$ & $25,10 \mathrm{c}$ & $31,10 \mathrm{c}$ & $35,50 \mathrm{c}$ \\
\hline BNT 5\% & 1,26 & 1,45 & 1,96 & 1,87 \\
\hline \multicolumn{5}{|l|}{ Usia Biakan } \\
\hline $\mathrm{U} 1$ & $15,80 \mathrm{ab}$ & $21,41 \mathrm{a}$ & $26,81 \mathrm{a}$ & $30,70 \mathrm{a}$ \\
\hline $\mathrm{U} 2$ & $16,94 \mathrm{~b}$ & $21,68 \mathrm{a}$ & $29,87 \mathrm{~b}$ & $34,49 \mathrm{~b}$ \\
\hline U 3 & $15,41 \mathrm{a}$ & $23,49 \mathrm{~b}$ & $25,89 \mathrm{a}$ & $30,86 \mathrm{a}$ \\
\hline BNT 5\% & 1,26 & 1,45 & 1,96 & 1,87 \\
\hline
\end{tabular}

Keterangan: Huruf yang sama dibelakang angka pada kolom yang sama, menunjukan perbedaan yang tidak nyata pada uji BNT (0,05). D0 (tanpa pemberian isolat Trichoderma spp.); D1 (250 $\mathrm{ml}$ biakan Trichoderma spp); D2 (500 biakan isolat Trichoderma spp).U1(usia biakan 1 minggu); U2 (usia biakan 2 minggu); U3 (usia biakan 3 minggu). ; Mst = minggu setelah tanam. 
Perlakuan usia biakan Trichoderma spp. 2 minggu (U2), pada pengamatan umur $2 \mathrm{Mst}$; $4 \mathrm{Mst}$ dan 5 Mst menghasilkan tinggi tanaman lebih tinggi dibandingkan dengan tinggi tanaman pada perlakuan usia biakan umur 1 minggu (U1) dan usia biakan umur 3 minggu (U3), kecuali pada pengamatan umur 3 Mst tinggi tanaman pada perlakuan usia biakan Trichoderma spp. 2 minggu (U2), lebih rendah dari perlakuan U 3. Tinggi tanaman pada perlakuan U 2, pada pengamatan umur 2 Mst; 4 Mst dan 5 Mst, berturut-turut adalah $15,84 \mathrm{~cm} ; 28,77$ $\mathrm{cm}$ dan $33,39 \mathrm{~cm}$ dan $12,84 \%$ lebih tinggi dari perlakuan U1, serta lebih tinggi $10,69 \% ; 11,55 \%$ dan $2,19 \%$ lebih tinggi dari perlakuan U3.

\section{Jumlah Daun.}

Hasil Analisa statistika (Tabel 3) menunjukkan bahwa perlakuan Trichoderma spp. dosis $500 \mathrm{ml}$ (D2) pada pengamatan umur $2 \mathrm{Mst} ; 3 \mathrm{Mst}$; 4 Mst dan 5 Mst, menghasilkan jumlah daun nyata tertinggi dibandingkan dengan perlakuan dosis $250 \mathrm{ml}$ (D1) dan tanpa pemberian Trichoderma spp. (D0) dengan jumlah daun terendah pada perlakuan D0. Jumlah daun pada perlakuan dosis D2, pada pengamatan umur 2 Mst; 3 Mst; 4 Mst dan 5 Mst, berturut-turut adalah 5,11 helai, 8,77 helai, 11 helai dan 13,22 helai dengan presentase lebih tinggi $9,42 \% ; 8,13 \% ; 2,13 \%$ dan $0 \%$ dari perlakuan D1, serta lebih tinggi $27,75 \% ; \quad 46,16 \% ; \quad 33,81 \%$ dan $26,62 \%$ dari perlakuan D0.

Tabel 3. Jumlah daun sawi pada dosis dan usia biakan Trichoderma spp.

\begin{tabular}{|c|c|c|c|c|}
\hline \multirow[t]{2}{*}{ Perlakuan } & \multicolumn{4}{|c|}{ Jumlah dau tanaman sawi (helai/tanaman) } \\
\hline & $2 \mathrm{Mst}$ & $3 \mathrm{Mst}$ & $4 \mathrm{Mst}$ & $5 \mathrm{Mst}$ \\
\hline D 0 & $4.22 \mathrm{a}$ & $6.22 \mathrm{a}$ & $8.44 \mathrm{a}$ & $10.66 \mathrm{a}$ \\
\hline D 1 & $4.89 \mathrm{~b}$ & $8.33 \mathrm{~b}$ & $10.99 \mathrm{~b}$ & $13.44 \mathrm{~b}$ \\
\hline D 2 & $5.33 \mathrm{~b}$ & $8.99 \mathrm{~b}$ & $11.22 \mathrm{~b}$ & $13.44 \mathrm{~b}$ \\
\hline BNT 5\% & 0.56 & 0.72 & 0.73 & 0.608 \\
\hline $\mathrm{U} 1$ & $4.44 \mathrm{a}$ & $7.55 \mathrm{a}$ & $9.78 \mathrm{a}$ & $11.98 \mathrm{a}$ \\
\hline $\mathrm{U} 2$ & $5.55 \mathrm{~b}$ & $8.66 \mathrm{~b}$ & $11.44 \mathrm{~b}$ & $13.89 \mathrm{~b}$ \\
\hline U 3 & $4.44 \mathrm{a}$ & $7.33 \mathrm{a}$ & $9.78 \mathrm{a}$ & $11.66 \mathrm{a}$ \\
\hline BNT 5\% & 0.56 & 0.72 & 0.73 & 0.608 \\
\hline
\end{tabular}

Keterangan: Huruf yang sama dibelakang angka pada masing-masing kolom menujukan perbedaan yang tidak nyata pada uji BNT $(0,05)$. D0 (tanpa pemberian isolat Trichoderma spp.); D1( $250 \mathrm{ml}$ biakan Trichoderma spp); D2 (500 $\mathrm{ml}$ biakan isolat Trichoderma spp).U1(usia biakan 1 minggu); U2 (usia biakan 2 minggu); U3 (usia biakan 3 minggu).

Perlakuan usia biakan Trichoderma spp. 2 minggu (U2), yaitu pada pengamatan umur $2 ; 3 ; 4$ dan 5 Mst memberikan jumlah daun tanaman nyata tertinggi dibandingkan dengan perlakuan usia biakan umur 1 minggu (U1) dan usia biakan umur 3 minggu (U3). Jumlah daun pada U2, pada pengamatan umur $2 \mathrm{Mst} ; 3 \mathrm{Mst}, 4$
Mst dan 5 Mst, berturut-turut adalah 5,33 helai; 8,44 helai; 11,22 helai dan 13,67 helai, sedangkan pada perlakuan U1 berturut-turut adalah 4,22 helai; 7,33 helai; 9,56 helai; dan 11,78 helai kemudian pada perlakuan U3 berturur-turut adalah 4,22 helai; 7,33 helai; 9,56 helai dan 11,78 helai (Tabel 3 dan Gambar 1). 


\section{Jumlah daun sawi}

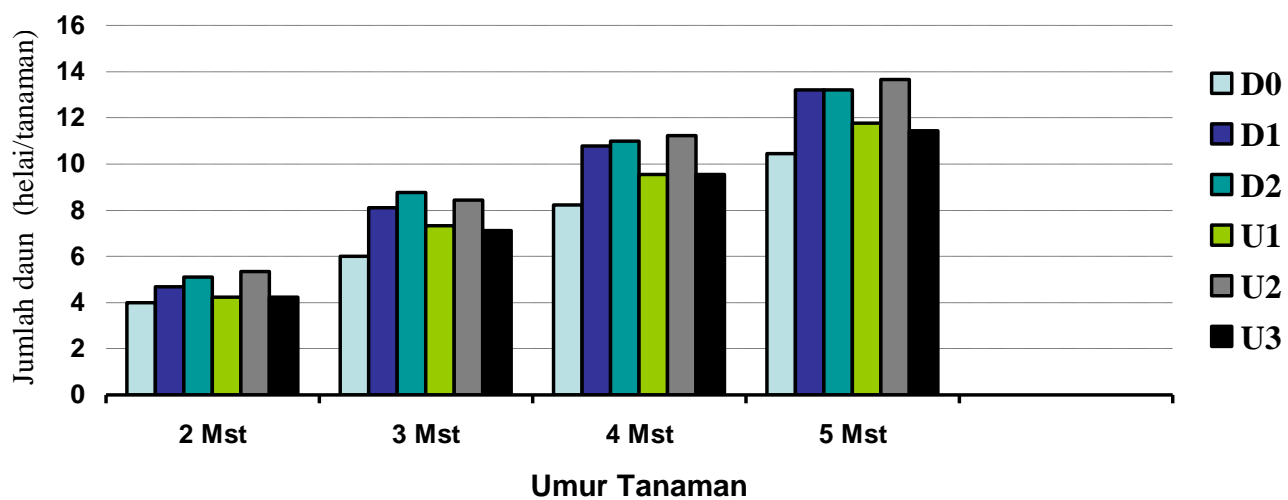

Gambar 1. Perkembangan jumlah daun sawi pada perlakuan dosis dan umur biakan isolat Trichoderma spp.

Keterangan : D0 (tanpa pemberian isolat Trichoderma spp.); D1( $250 \mathrm{ml}$ biakan Trichoderma spp); D2 (500 $\mathrm{ml}$ biakan isolat Trichoderma spp).U1(usia biakan 1 minggu); U2 (usia biakan 2 minggu); U3 (usia biakan 3 minggu). ; Mst = minggu setelah tanam

\section{Persentase Serangan Penyakit}

Hasil Analisa statistika (Tabel 4) menunjukkan bahwa pada pengamatan umur $1 \mathrm{Msi}, 2$ Msi dan 3 Msi, perlakuan dosis dan usia biakan Trichoderma spp. memberikan pengaruh yang sangat berbeda nyata terhadap parameter persentase serangan penyakit. Kombinasi perlakuan dosis dan usia biakan memberikan pengaruh persentase serangan yang tidak berbeda nyata pada pengamatan 1 Msi, berbeda nyata pada pengamatan 2 Msi dan sangat berbeda nyata pada pengamatan 3 Msi.

Tabel 4. Persentase penyakit akar gada pada tanaman sawi setelah inokulasi isolat Trichoderma spp.

\begin{tabular}{cccc}
\hline \multirow{2}{*}{ Perlakuan } & \multicolumn{3}{c}{ Persentase serangan penyakit (\% ) } \\
\cline { 2 - 4 } & $1 \mathrm{Msi}$ & $2 \mathrm{Msi}$ & $3 \mathrm{Msi}$ \\
\hline D 0 & $64.44 \mathrm{c}$ & $77.77 \mathrm{c}$ & $93.33 \mathrm{c}$ \\
D 1 & $39.99 \mathrm{~b}$ & $48.88 \mathrm{~b}$ & $53.33 \mathrm{~b}$ \\
D 2 & $17.77 \mathrm{a}$ & $22.22 \mathrm{a}$ & $24.44 \mathrm{a}$ \\
\hline BNT 5\% & 1.452 & 1.35 & 1.08 \\
\hline U 1 & $44.44 \mathrm{a}$ & $53.33 \mathrm{a}$ & $57.77 \mathrm{~b}$ \\
U 2 & $79.99 \mathrm{c}$ & $65.55 \mathrm{c}$ & $44.44 \mathrm{a}$ \\
U 3 & $51.10 \mathrm{~b}$ & $59.99 \mathrm{~b}$ & $74.88 \mathrm{c}$ \\
\hline BNT 5\% & 1.452 & 1.35 & 1.08 \\
\hline
\end{tabular}

Keterangan: Huruf yang sama dibelakang angka pada masing-masing kolom menujukan perbedaan yang tidak nyata pada uji BNT $(0,05)$.

D0 (tanpa pemberian isolat Trichoderma spp.); D1( $250 \mathrm{ml}$ biakan Trichoderma spp); D2 (500 ml biakan isolat Trichoderma spp).U1(usia biakan 1 minggu); U2 (usia biakan 2 minggu); U3 (usia biakan 3 minggu). Msi = minggu setelah inokulasi. 


\section{Persentase penyakit}

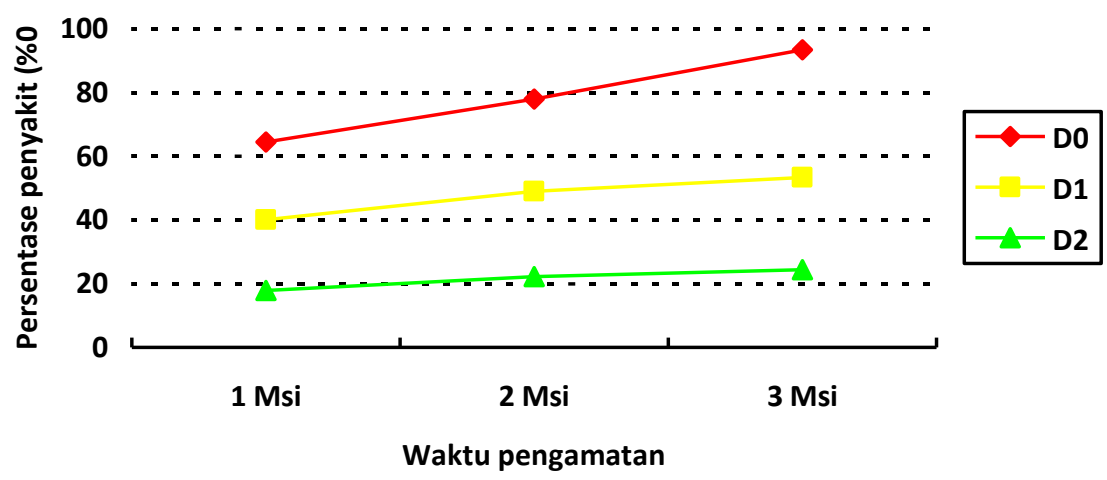

Gambar 2. Perkembangan persentase penyakit akar gada pada tanaman sawi setelah inokulasi beberapa dosis isolat Trichoderma spp

Keterangan: D0 (tanpa pemberian isolat Trichoderma spp.); D1( $250 \mathrm{ml}$ biakan Trichoderma spp); D2 (500 $\mathrm{ml}$ biakan isolat Trichoderma

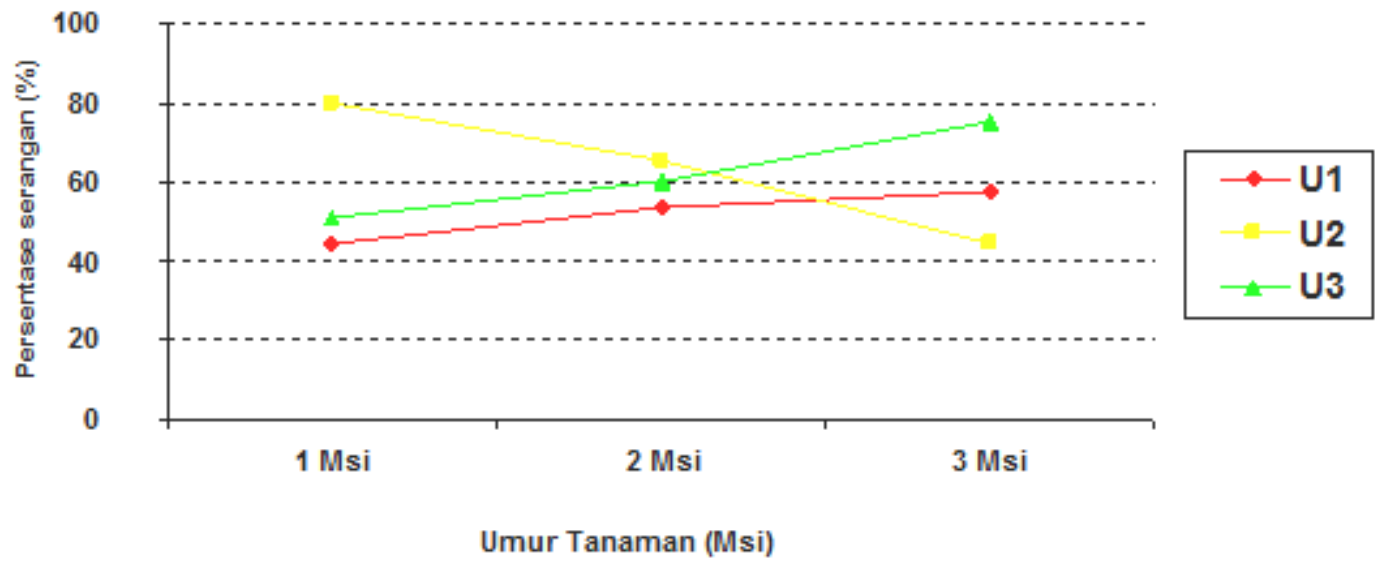

Gambar 3. Perkembangan persentase penyakit akar gada pada tanaman sawi setelah inokulasi beberapa usia biakan isolat Trichoderma spp.

Keterangan : U1(usia biakan 1 minggu); U2 (usia biakan 2 minggu);

U3 (usia biakan 3 minggu).; Msi = minggu setelah inokulasi

Perlakuan Trichoderma spp. dosis $500 \mathrm{ml}$ biakan (D2) pada pengamatan umur $1 ; 2$ dan $3 \mathrm{Msi}$, memberikan persentase serangan terkecil dibandingkan dengan perlakuan dosis $250 \mathrm{ml}$ biakan (D1) dan tanpa pemberian Trichoderma spp. (D0) dengan persentase serangan tertinggi terjadi perlakuan D0.
Persentase serangan pada perlakuan dosis D2, pada pengamatan umur 1 Msi; 2 Msi dan 3 Msi, berturut-turut adalah $17,77 \% ; 22,22 \%$ dan $24,44 \%$ (Tabel 4 dan Gambar 2).

Perlakuan usia biakan Trichoderma spp. 2 minggu (U2), pada pengamatan umur $1 \mathrm{Msi}$; $2 \mathrm{Msi}$ dan 3 Msi memberikan persentase 
serangan terendah dibandingkan dengan perlakuan usia biakan umur 1 minggu (U1) dan usia biakan umur 3 minggu (U3) dengan persentase Pengaruh kombinasi dosis dan usia biakan isolat Trichoderma spp.

Hasil Analisa statistika (Tabel 5) menunjukkan bahwa pengaruh kombinasi perlakuan terhadap tinggi tanaman pada umur 5 Mst, menujukan pengaruh yang berbeda

Tabel 5. Tinggi tanaman, jumlah daun dan persentase penyakit akar gada tanaman sawi pada perlakuan

\begin{tabular}{|c|c|c|c|}
\hline \multirow[b]{2}{*}{ Perlakuan } & \multicolumn{2}{|c|}{ Umur tanaman $5 \mathrm{Mst}$} & \multirow{2}{*}{$\begin{array}{l}\text { Persentase serangan } \\
\text { penyakit umur } 3 \text { Msi } \\
(\%)\end{array}$} \\
\hline & $\begin{array}{l}\text { Tinggi tanaman } \\
(\mathrm{cm})\end{array}$ & $\begin{array}{c}\text { Jumlah daun } \\
\text { (helai) }\end{array}$ & \\
\hline D $0 \mathrm{U} 1$ & $27,60 \mathrm{ab}$ & $10,00 \mathrm{a}$ & $93,33 \mathrm{~d}$ \\
\hline $\mathrm{D} 0 \mathrm{U} 2$ & $30,83 \mathrm{bc}$ & $11,00 \mathrm{ab}$ & $93,33 \mathrm{~d}$ \\
\hline D $0 \mathrm{U} 3$ & $26,27 \mathrm{a}$ & $10,33 \mathrm{a}$ & $93,33 \mathrm{~d}$ \\
\hline D $1 \mathrm{U} 1$ & $30,50 \mathrm{bc}$ & $13,00 \mathrm{c}$ & $60,00 \mathrm{c}$ \\
\hline D 1 U 2 & $31,00 \mathrm{~cd}$ & $14,67 \mathrm{~d}$ & $40,00 \mathrm{c}$ \\
\hline D 1 U 3 & $28,83 \mathrm{abc}$ & $12,00 \mathrm{bc}$ & $60,00 \mathrm{c}$ \\
\hline D $2 \mathrm{U} 1$ & $30,70 \mathrm{bc}$ & $12,33 \mathrm{c}$ & $20,00 \mathrm{~b}$ \\
\hline D 2 U 2 & $38,33 \mathrm{e}$ & $15,33 \mathrm{~d}$ & $00,00 \mathrm{a}$ \\
\hline D 2 U 3 & $34,17 \mathrm{~d}$ & $12,00 \mathrm{bc}$ & $53,33 \mathrm{c}$ \\
\hline BNT 5\% & 3,24 & 1,053 & 1,874 \\
\hline
\end{tabular}

Keterangan:

Huruf yang sama dibelakang angka pada masing-masing kolom menujukan perbedaan yang tidak nyata pada uji BNT $(0,05)$.

D0 (tanpa pemberian isolat Trichoderma spp.); D1( $250 \mathrm{ml}$ biakan Trichoderma spp); D2 (500 ml biakan isolat Trichoderma spp).U1(usia biakan 1 minggu); U2 (usia biakan 2 minggu); U3 (usia biakan 3 minggu). ; Msi = minggu setelah inokulasi.

Kombinasi dari perlakuan terhadap jumlah daun tanaman pada umur 5 Mst, menujukan pengaruh yang berbeda nyata. Jumlah daun tanaman pada kombinasi perlakuan D2U2 mencapai 15,33 helai nyata tertinggi dibandingkan dengan kombinasi perlakuan lain dan jumlah daun tanaman terkecil terjadi pada perlakuan kombinasi D0U1 yaitu 10,00 helai .

Pengaruh dari kombinasi perlakuan terhadap persentase serangan tertinggi terjadi pada perlakuan U3 (Tabel 4 dan Gambar $3)$.

nyata. Tinggi tanaman pada kombinasi perlakuan D2U2 yaitu $38,33 \mathrm{~cm}$ nyata tertinggi dibandingkan dengan kombinasi perlakuan lain dan tinggi tanaman terendah terjadi pada perlakuan kombinasi D0U3 yaitu 26,27 cm. kombinasi dosis dan usia biakan isolat Trichoderma spp. 
Persentase penyakit $(\%)$

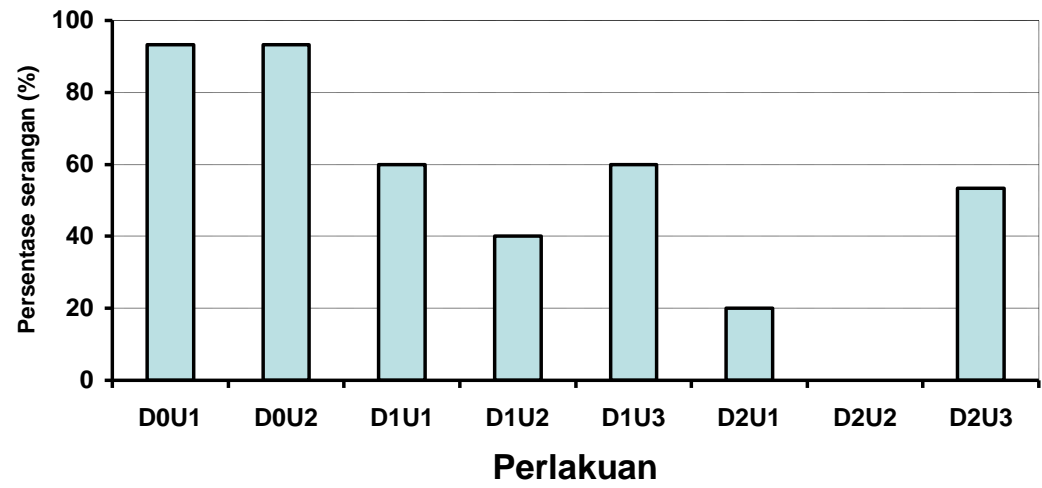

Gambar 4. Persentase penyakit akar gada tanaman sawi umur 3 Msi pada kombinasi perlakuan dosis dan usia biakan isolat Trichoderma spp.

Keterangan: D0 (tanpa pemberian isolat Trichoderma spp.); D1( $250 \mathrm{ml}$ biakan Trichoderma spp); D2 (500 $\mathrm{ml}$ biakan isolat Trichoderma spp).U1(usia biakan 1 minggu); U2 (usia biakan 2 minggu); U3 (usia biakan 3 minggu).

\section{Pembahasan}

Hasil penelitian menunjukkan bahwa pada taanaman sawi yang terinfeksi penyakit akar gada pemberian isolat Trichoderma spp. memberikan pengaruh yang sangat nyata terhadap persentase serangan penyakit, yaitu pemberian dosis isolat Trichoderma spp. $500 \mathrm{ml}$ memberikan persentase serangan penyakit terkecil dibandingkan dengan perlakuan isolat Trichoderma spp. dosis $250 \mathrm{ml}$ dan tanpa pemberian Trichoderma spp.. Dari hasil penelitian ini ternyata bahwa Trichoderma spp. mampu menekan perkembangan pathogen penyebab penyakit akar gada. Hasil ini sejalan dengan hasil penelitian (Yudha et al., 2016) yaitu perlakuan Trichoderma isolat bawang efektif dalam mengendalikan penyakit akar gada dan meningkatkan hasil tanaman caisin, dengan menekan intensitas penyakit di atas tanah sebesar 50,00 $\%$, menekan intensitas di dalam tanah sebesar $34,48 \%$. Selanjutnya Purwantisari \& Hastuti (2009), menyatakan bahwa Trichoderma spp. dapat menekan pertumbuhan jamur patogen dengan cara antibiosis yaitu penghambatan patogen oleh senyawa metabolik yang dihasilkan. Selanjutnya Herman et al., (2014), menyatakan bahwa kompetisi terjadi yaitu jamur agen hayati tumbuh dan mengambil makanan serta mengganggu pertumbuhan jamur pathogen. Trichoderma spp. bersifat hiperparasit yaitu sebagai perusak pathogen oleh senyawa yang dihasilkan agen hayati dengan cara melisiskan hifa. Karena Trichoderma spp. memiliki miselium yang mampu menghasilkan bermacam-macam enzim yaitu enzim selulase (pendegradasi selulosa), enzim hemiselulase (pendegradasi hemiselulosa) (Sukadarti et al., 2010) dan enzim glukanase (Herlina, 2009).

Tinggi tanaman dan jumlah daun tanaman sawi yang terinfeksi pathogen akar gada dari hasil penelitian ini menunjukkan ternyata bahwa pemberian isolat Trichoderma 
spp. pada dosis $500 \mathrm{ml}$ memberikan hasil nyata lebih baik dibandingkan dengan perlakuan tanpa pemberian isolat Trichoderma spp. dan perlakuan pemberian isolat Trichoderma spp. dosis $250 \mathrm{ml}$. Hasil ini terjadi sebagai dampak dari adanya aktifitas Trichoderma spp. yang diberikan. Hasil ini terjadi karena isolat Trichoderma spp. dapat membantu pertumbuhan tanaman melalui proses penyediaan unsurunsur hara di dalam tanah. Perlakuan Trichoderma sp. sebagai agensia hayati mampu meningkatkan pertumbuhan tanaman, sesuai dengan pernyataan Rahayuniati \& Mugiastuti (2009), bahwa Trichoderma sp. juga mampu menguraikan bahan organik di dalam medium, sehingga menjadi struktur yang lebih sederhana, mudah larut dan dapat dimanfaatkan tanaman sebagai sumber nutrisi untuk pertumbuhan tanaman. Azarmi et al., (2011) juga berpendapat bahwa pemberian Trichoderma sp. dapat meningkatkan jumlah dan lebar daun serta mampu meningkatkan kadar klorofil pada daun. Dilain pihak Sudhanta dan Abdul (2011) menyatakan bahwa Trichoderma merupakan salah satu jenis mikrob yang memiliki kemampuan dalam menghambat pertumbuhan patogen dengan menghasilkan senyawa aktif biologis secara in vitro. Senyawa aktif tersebut meliputi alkaloid, paxillin, lolitrems, dan tetranone steroid. Selanjutnya terjadi persaingan akibat adanya kebutuhan yang sama dari masing masing cendawan, yaitu kebutuhan tempat tumbuh dan nutrisi media yang digunakan untuk tumbuh (Ara et al., 2012).

Hasil penelitian juga menunjukkan bahwa persentase serangan penyakit akar gada nyata tertinggi terjadi pada perlakuan tanpa pemberian isolat Trichoderma spp. kemudian menurun pada perlakuan pemberian isolat Trichoderma spp. dosis $250 \mathrm{ml}$. Persentase serangan penyakit akar gada pada pemberian Trichoderma spp. $250 \mathrm{ml}$ belum dapat menghasilkan persentase serangan penyakit terkecil, hal ini terjadi karena populasi dari Trichoderma spp. yang ada belum berkebang sepenuhnya untuk mampu memainkan sifat antagonistiknya terhadap patogen lain di dalam tanah. Hal ini berdampak terhadap hasil tinggi tanaman dan jumlah daun tanaman sawi yang terinfeksi pathogen akar gada yaitu nyata lebih rendah dari pemberian isolat Trichoderma spp. dosis $500 \mathrm{ml}$. Hasil ini sejalan dengan pendapat Anonim (2012), yang menyatakan bahwa ingkat produksi tanaman kubis sering kali dipengaruhi oleh serangan patogen yang menyebabkan bengkak pada akar dan pembengkakan pada jaringan akar dapat mengganggu fungsi akar seperti translokasi zat hara dan air dari dalam tanah kedaun sehingga keadaan ini mengakibatkan tanaman layu, kerdil, kering dan akhirnya mati.

Perlakuan perbedaan usia biakan Trichoderma spp. pada tanaman sawi yang terinfeksi pathogen penyakit akar gada memberikan pengaruh bebeda nyata terhadap kemampuan pengendalian penyakit yang ditunjukkan dari persentase serangan penyakit. Perkembangan persentase serangan penyakit akar gada pada tanaman sawi yang terinfeksi, dari hasil penelitian ini menunjukkan bahwa pada pelakuan usia biakan Trichoderma spp. 2 minggu pada setiap waktu pengamatan, yaitu 1 minggu, 2 mingga dan 3 minggu setelah inokulasi inokulum akar gada 
menghasilkan persentase serangan penyakit tekecil, dibandingkan dengan perlakuan usia biakan umur 1 minggu dan usia biakan umur 3 minggu. Hasil ini terjadi karena pada isolat Trichoderma spp. usia biakan 2 minggu tersebut aktivitas dan perkembangan populasi isolat berada pada kondisi yang optimum, sehingga mempunyai kemampuan didalam melakukan aktivitas antagonistik yang lebih tinggi dibanding usia biakan 1 minggu dan 3 minggu. Mekanisme antagonis yang dilakukan Trichoderma spp. dalam menghambat pertumbuhan patogen antara lain kompetisi, parasitisme, antibiosis, dan lisis (Purwantisari \& Hastuti, 2009). Menurut Alfizar et al. (2013), mekanisme antagonisme dari Trichoderma spp. terhadap cendawan patogen dilakukan dengan mengeluarkan toksin berupa enzim $\beta$ 1,3 glukanase, kitinase, dan selulase yang dapat menghambat pertumbuhan bahkan dapat membunuh patogen. Molekul antibiosis yang dihasilkan oleh Trichoderma spp adalah 1,3 glukanase dan khitinase. Enzim kedua tersebut menghancurkan glukan dan kitin yang merupakan komponen dinding hifa dari beberapa cendawan tanaman patogen.

Pada pengamatam 3 minggu setelah inokulasi persentase serangan penyakit tertinggi terjadi pada perlakuan Trichoderma spp. usia biakan 3 minggu yaitu mencapai $74,88 \%$.. Hal ini terjadi karena perkembangan hipha dari isolate Trichoderma spp. telah mengalami penurunan efektivitas sifat kompetisinya terhadap patogen lain di dalam tanah. Hasil ini didukung oleh Wahyuno et al. (2009), yang menyatakan bahwa Trichoderma sp. dalam peranan sebagai agensia hayati bekerja berdasarkan beberapa mekanisme antagonistik, salah satunya yaitu kompetisi. Kompetisi terjadi ketika dua atau lebih koloni mikroorganisme saling berkompetisi dalam memperebutkan kebutuhan hidup yang sama dalam ruang dan waktu yang sama. Sifat kompetisi antara agen antagonis dengan patogen penyakit memegang peranan penting dalam pengendalian penyakit.

Pemberian agen hayati isolat Trichoderma spp. pada tanaman sawi yang terinfeksi akar gada, dengan kombinasi dosis $500 \mathrm{ml}$ dan usia biakan 2 minggu memberikan hasil terbaik bila dibandingkan dengan kombinasi dosis dan usia biakan lain dalam penelitian ini. Hasil tersebut ditunjukkan oleh tinggi tanaman dan jumlah daun tertinggi serta persentase serangan penyakit terendah yaitu mencapai $0 \%$ (tanpa serangan penyakit). Dari hasil ini ternyata bahwa dosis isolat Trichoderma spp. $500 \mathrm{ml}$ dan usia biakan. 3 minggu yang diberikan berada dalam kondisi efektifitas antagonistik yang terbaik. Hasil ini terjadi karena lamanya masa inkubasi yang tepat pada saat penumbuhan Trichoderma spp. sehingga diperoleh jumlah hifa spora yang cukup untuk melakukan intervensi pada patogen. Intervensi hifa oleh Trichoderma mengakibatkan adanya perubahan unsur kimia dan partikel pada dinding sel sehingga dapat memengaruhi permeabilitas dinding sel pathogen (Carreras-Villaseñor et al., 2012).

Hifa antagonis yang berhasil melakukan intervensi dan penetrasi akan menyerap sari makanan sehingga hifa cendawan patogen dapat mengecil dan mati. Selanjutnya 
diketahui Trichoderma spp. mampu menghambat pertumbuhan dari Phytophthora infestans (Purwantisari \& Hastuti, 2009), Phytium sp. (Octriana, 2011), Diplodia sp. (Sundari et al., 2014), dan beberapa jamur patogen lainnya.

\section{SIMPULAN}

$\begin{array}{cccc}\text { Pada } & \text { tanaman } & \text { sawi } & \text { yang } \\ \text { terinfeksi } & \text { penyakit } & \text { akar } & \text { gada }\end{array}$ pemberian beberapa dosis isolat Trichoderma spp. dan beberapa usia biakan Trichoderma spp. memberikan pengaruh yang berbeda nyata terhadap tinggi tanaman, jumlah daun dan persentase serangan penyakit. Pemberian isolat Trichoderma spp. dosis $500 \mathrm{ml}$ menghasilkan tinggi tanaman 21,68\% dan jumlah dauan 26,63 \% nyata lebih tinggi dari tinggi tanan dan jumlah daun pada perlakuan tanpa pemberian isolat Trichoderma spp. Pemberian isolat Trichoderma spp. usia biakan 2 minggu menghasilkan tinggi tanaman $12,80 \%$ dan jumlah daun $16,04 \%$ nyata lebih tinggi dari tinggi dan jumlah daun pada perlakuan usia biakan isolat Trichoderma spp. 1 minggu. Persentase serangan penyakit mencapai $0 \%$ pada perlakuan kombinasai dosis biakan isolat Trichoderma spp. $500 \mathrm{ml}$ dengan usia biakan 2 minggu.

\section{UCAPAN TERIMA KASIH}

Terimakasih disampaikan penulis kepada Rektor dan Dekan beserta stap Fakultas Pertanian dan Bisnis Universitas Mahasaraswati Denpasar, atas ijin penggunaan Laboratorium Fakultas Pertanian dan Bisnis selama pelaksanaan penelitian.

\section{DAFTAR PUSTAKA}

Alfizar, Marlina, \& Susanti, F.
(2013). Kemampuan Antagonis Trichoderma sp. terhadap Beberapa Jamur Patogen in vitro. Jurnal Floratek, 8(1), 4551.

Anonim. (2012). Akar gada Plasmodiophora brassicae, pada kubis.

Ara, I. H., Rizwana, Al-Othman, M., \& Baki, M. (2012). Antagonism of actinomycete against Pestalotiopsis mangiferae, causal agenst of mango brown rot in post harvest storage. Afr. J. Microbiol. Res., Vol. 6, No. 8, Pp. 1782-9., 6(8), 1782-1789.

Arismansyah, E. A. (2010). Penyakit akar gada (Plasmodiophora brassicae Wor) pada kubiskubisan dan upaya pengendaliannya.

http://erlanardianarismansyah.w ordpress.com/2010/01/07/penya kit-akar-gada-plasmodiophorabrassicae-wor-pada-kubiskubisan-dan upayapengendaliannya.

Azarmi, R., Hajieghrari, B., \& Giglou, A. (2011). Effect of Trichoderma isolates on tomato seedling growth response and nutrient uptake. African Journal of Biotechnology, 10(31), 58505855.

https://doi.org/10.5897/AJB10.1 600

Carreras-Villaseñor, N., SánchezArreguín, J. A., \& HerreraEstrella, A. H. (2012). Trichoderma: sensing the environment for survival and dispersal. Microbiology, 158(1), 3-16.

https://doi.org/10.1099/mic.0.05 2688-0

Herlina, L. (2009). Potensi Trichoderma harzianum sebagai Biofungisida pada Tanaman 
Tomat. Biosantifika, 1(1), 1-7.

Mahartha, K. A., Khalimi, K., \& Wirya, G. N. A. S. (2013). Efektivitas Rhizobakteri sebagai Agen Antagonis terhadap Fusarium oxysporum f.sp. capsici Penyebab Penyakit Layu Fusarium pada Tanaman Cabai Rawit (Capsicum frutescens L.). E-Jurnal Agroekoteknologi Tropika, 2(3), 145-154.

Octriana, L. (2011). Potensi Agen Hayati dalam Menghambat Pertumbuhan Phytum sp. secara In Vitro. Buletin Plasma Nuftah, 17(2), 138-142.

Pratiwi, D. A., Gutomo, H. S., \& Hadiwiyono, H. (2015). Pengendalian Infeksi Akar Gada pada Pembibitan Kubis dengan Pupuk Hijau Daun Paitan. Agrosains: Jurnal Penelitian Agronomi, $\quad$ 17(2), 27. https://doi.org/10.20961/agsjpa. v17i2.18664

Purwantisari, S., \& Hastuti, R. B. (2009). Uji Antagonisme Jamur Patogen Phytophthora infestans Penyebab Penyakit Busuk Daun dan Umbi Tanaman Kentang Dengan Menggunakan Trichoderma spp. Isolat Lokal. Bioma, 11(1), 24-32.

Rahayuniati, R. F., \& Mugiastuti, E. (2009). Pengendalian penyakit layu fusarium tomat: aplikasi abu bahan organik dan jamur antagonis. Jurnal Pembangunan Pedesaan, 9(1), 25-34.

Rao, S. N. S. (2010). Mikroorganisme Tanah \& Pertumbuhan Tanaman. UI Press.

Sudantha, I. M., \& Abadi, A. L. (2011). Uji Efektivitas Beberapa Jenis Jamur Endofit Trichoderma spp. Isolat Lokal NTB Terhadap Jamur Fusarium oxysporum f. sp. vanillae Penyebab Penyakit Busuk Batang Pada Bibit Vanili. Crop Agro, 4(2), 64-73.

Sukadarti, S., Kholisoh, S. D., Prasetyo, H., Santoso, W. P., \& Mursini, T. (2010). Produksi Gula Reduksi dari Sabut Kelapa Menggunakan Jamur Trichoderma reesei. Prosiding Seminar Nasional Teknik Kimia "Kejuangan" Pengembangan Teknologi Kimia Untuk Pengolahan Sumber Daya Alam Indonesia.

Sundari, A., Khotimah, S., \& Linda, R. (2014). Daya Antagonis Jamur Trichoderma sp. Terhadap Jamur Diplodia sp. Penyebab Busuk Batang Jeruk Siam (Citrus nobilis). Jurnal Protobiont, 3(2).

Wahyuno, D., Manohara, D., \& Mulya, K. (2009). Peranan bahan organik pada pertumbuhan dan daya antagonisme Trichoderma harzianum dan pengaruhnya terhadap P. capsici. pada tanaman lada. Jurnal Fitopatologi Indonesia, 7, 7682.

Yudha, M. K. M., Soesanto, L., \& Mugiastuti, E. (2016). Pemanfaatan empat isolat Trichoderma sp. untuk mengendalikan penyakit akar gada pada tanaman caisin. Jurnal Kultivasi, 15(3), 143149.

https://doi.org/10.24198/kultivas i.v15i3.11771 